\title{
The embarrassment of imperfection: Galen's assessment of Hippocrates' linguistic merits
}

\author{
INEKE SLUITER
}

\begin{abstract}
Summary In antiquity the 'higher' study of medicine shared with many other disciplines a pronounced philological character Galen both exploited this 'philological paradigm' and underwent its influence He exploited it in that it enabled him to invest the Corpus Hippocratzcum with a dignity comparable to that of Homer only But his philological instrumentarium, originally designed for the study of literary texts, also forced him to pose and answer certain questions that shed no light whatsoever on the informational content of Hippocrates' writings, questions about Hippocrates' language and style Galen disentangles himself from the ensuing embarrassment by claiming that Hippocrates' style was ideal for the specific didactic genre he was involved in This special style necessitates a reassessment of customary grammatical and rhetorical values correctness recedes into the background, clarity and brevity become the predominant virtues of style
\end{abstract}

\section{Introduction}

When Galen set out to develop his own particular brand of Hippocratısm, bolstering the second-century-AD medical state of the art with all the authority of the ancient master, ${ }^{1}$ there could be no serious question as to how he was to set about this task the obvious and traditional way to study Hippocrates was through philology As a matter of fact, for several hundred years the 'higher', scientific type of ancient medicine had had a quite pronounced philological character ${ }^{2}$ Editions of the Corpus Hippocraticum had been and still were being prepared, lexicographical work had been going on at least since Herophilus and Bacchius ${ }^{3}$ and exegetıcal questions had been tackled at least

Research for this article has been made possible by a fellowshıp of the Royal Netherlands Academy of Arts and Sciences I wish to thank Dr and Mrs M A Stubbings of Kidlington for their much appreciated contributions in the technical, nutritive and recreational spheres (not necessarly in that order)

1 Cf Temkın (1973) 33, Smıth (1979) 91, 96, 106, 175 f, Manulı (1983) $474 \mathrm{f}$, contra Kollesch (1981) 9, I do not believe the difference between Hippocratic and Galenic medicine was quantitative only

2 Cf Vegett1 (1981) 48-52

3 Ilberg (1890) $111 \mathrm{ff}$, Wellmann (1931) I ff, of Gal Linguarum seu dictionum exoletarum Hippocratzs explicatzo, Proœem (1965 K) 
from the days of Herophilus ${ }^{4}$ Indeed, there was no ancient writer - except for Homer - who could boast an equally impressive amount of philological attention Only Biblical philology was to outstrip both Homer and Hippocrates in this respect All in all, technical philology, as developed for the study of Homer and other ancient literary paragons, seemed the perfect instrument to unravel the complex knots of the Hippocratic tradition, for the tradition of the works ascribed to Hippocrates posed problems very similar to the ones encountered in Homeric studies 5

When the poems of Homer, Hesiod and the Orphic cosmogonies first elicited comment (from the sixth century $\mathrm{BC}$ onwards), they were judged and valued for their cognitive contents at least as much as for their literary merits, and their first commentators were philosophers However, as grammarians and rhetoricians claimed an increasingly large role in linguistic studies, the emphasis shifted to purely grammatical and stylistic matters, although 'Realienforschung' never ceased to form part of the grammarıans' work, and there was a contınuing strong influence from philosophical quarters But, nevertheless, technical philology as developed by the great Homeric scholars of Alexandria and passed on to the ancient doctor-grammarians, was primarily an instrument for the study of literary and/or poetic texts from a literary and/ or poetic point of view

Poets like Homer were studied by grammarians and rhetoricrans alıke - in fact, their disciplines not only had a considerable mutual influence on each other, but are often rather hard to distinguish from each other in practice There is no clear-cut borderline between the work of the grammarran and that of the rhetorician The more strictly grammatical approach would concentrate on two sets of problems providing reiable texts was the 'diorthotic' or textcritical part of the grammarians' job, studying grammatical correctness in general (Hellênusmos or Latzntas) would constitute therr main other topic For the proper execution of both tasks they would rely heavily on the so-called 'Kriterien der Sprachrıchtigkett', 6 implemented differently for diorthosts and for the study of Hellênismos In both cases they would tackle problems by applying a rational principle, either their common sense or a set of acknowledged grammatıcal rules (ratıo or analogia) Further they would use an empirical criterion, viz their knowledge of the specific idiom of the author they were dealıng with (In diorthôsts), or their knowledge of contemporary educated usage (for studies of Hellênismos) This criterion is usually referred to as sunêtheta (consuetudo, 'ordinary usage') The third main criterion is called paradosis, (traditıo, 'tradition') For diorthotic purposes this means previous editions of

4 Mewaldt (1909) 129, Deichgraber (1965) $320 \mathrm{f}$

5 Mewaldt (1909) $131 \mathrm{ff}$

6 Siebenborn (1976), Sluter (1990) 54-61

7 For the connection between historia and paradosts, cf Deichgraber (1965) 126 ff, $298 \mathrm{f}$ 
the work of the author in question, with the learned comments, if any, by earlier scholars In the studies of grammatical correctness, this criterion would encompass the literary tradition at large The results of bistoria could be relevant here, too 7 The authority of great writers from the past, Homer most prominent among them, was used to legitımize the use of certain locutions In a sense, 'tradition' is, of couise, no more than 'everyday educated usage from the past', so that it is quite closely related to the empirical criterion of sunêthera But the palaion (veteres, the 'ancients') were regarded with special respect Incidentally, these sets of criteria need not be mutually exclusive some grammarıans (e g Apollonius Dyscolus) combined both in their linguistic studies 8

Thus, the 'grammatical' approach concentrated on textual criticism and the study of grammatical correctness Rhetoricians, on the other hand, focused on a stylistic analysis, gravitating around the theory of the virtues and vices of style And their results, too, would leave traces in (predominantly grammat1cal) scholia and other ancient literary studies Especially in the case of Homer - although this holds good for other poets as well - we find that the status of being a poet warranted an almost reverential circumspection what would constitute a fault or a mistake in a lesser author would be styled a figure of speech in Homer and was held to contribute to his stylistic superiority In the case of deviations from normal linguistic usage an appeal could also be made to poetic licence, as well as to the ultımate (and related) expedient of metr causa And Homer's authority would be enough to uphold the claims of any such deviant usage against (or alongside) the normal colloquial one

All in all, there were strongly literary and purely linguistic elements in the technical instrumentarium Galen inherited when he started his impressive auvre - which can essentially be described as the result of a continuous process of intertextuality vis-à-vis the Corpus Hippocratıcum Instead of simply going its own way, Hippocratic philology never ceased to undergo the influence of contemporary developments in its literary counterpart Galen himself was a very accomplished philologist ${ }^{9}$ He shows great acumen and a steady hand in applying the tools of this trade But the very nature of these tools, primarily

8 Blank (1982, $12 \mathrm{ff})$ has pointed out that there is a marked simularity in the epistemological position of the contemporaries Galen, Claudius Ptolemy and Apoilonius Dyscolus All three combine rational and empirical elements in therr theory of knowledge Galen, of course, projects this attitude (with all three criteria) backwards to Hippocrates (In Hippocratts Prorrbeticum I commentaru $115[16550$ K ]) '( ) adding rational judgement to his results obtained by research of the sources

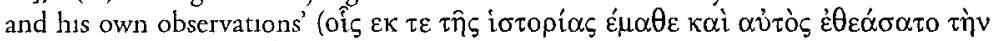
$\lambda$ خ position, see further Frede (1981) For a more exclusive concentration on the two main ingredients (rational and empirical) of this epistemology, see De methodo medendt 44 (10 $272 \mathrm{~K}$ ), Frede (1981) 77

9 Cf von Muller (1891), I have been unable to see von Muller (1892) 
designed for the analysis of literary texts, entails certan consequences for the questions Galen tends to ask He is almost obliged to pass a verdıct on Hippocrates' literary merıts, his style, and even the purity of his language This corresponds to the more rhetorical and the more grammatical approaches distunguished above In commenting on these aspects, however, Galen does show an awareness of the incongruity of his linguistic strategy with the manly cognitive interest the Huppocratic texts provoke The ensuing tension is the topic of this paper In the remainder of this article I will investigate Galen's lingustic report on Hippocrates, encompassing some of his comments on grammatical, stylistic and literary characteristics found in the Corpus Hippocrattcum, his defence of what he found, and the consequences for his personal stylistic ideal My findings may be seen as an illustration of the way in which medical studies conformed to an essentially language-oriented scientific paradigm of antiquity

\section{Galen on Hippocrates' language and style}

On a number of occastons Galen comments farly explicitly on the purity of language and the style of 'the great Hippocrates ( ) who was considered the best doctor and prosast among the Greeks themselves' 10 Where lexical and syntactical purity are concerned, Hippocrates' record may not be altogether impeccable, but Galen stages a very determened defence, even to the point of declaring that a particular instance of inaccuracy was contrived on purpose to stımulate the alertness of his readers ${ }^{11}$ Moreover, he uses the frequent occurrence of linguistic mistakes or faulty constructions in any work as an argument against its authenticity ${ }^{12}$ In accordance with normal grammatical theory, Galen distinguishes three major kinds of 'grammatıcal' mistakes barbarısms (mistakes on a phonological level), solecisms (mistakes affecting the meaning and construction), and akurologia, the improper or inaccurate use of single words ${ }^{13}$ To the best of my knowledge he never accuses Hippocrates of com-

10 In Hippocratzs librum De fracturts commentarn 11 (18B $324 \mathrm{~K}$ ), on Galen's account of Hippocrates' style, see Manulı (1983) 473

11 In Hippocratis De articulis librum commentaru $124(18 \mathrm{~A} 352 \mathrm{f} \mathrm{K})$, of In Hippocratus librum De medici officina commentarn 15 (18B $665 \mathrm{~K})$

$12 \mathrm{Eg}$ In $H_{\imath p p}$ Prorrhet comment $14(16511 \mathrm{ff} \mathrm{K})$, ibid $(16514 \mathrm{~K})$, In Hippocratus Aphortsmos commentarn 562 (17B $865 \mathrm{~K})$, ibid 769 (18A $183 \mathrm{f} \mathrm{K}$ ) 'well, this inaccurate use of nouns and verbs is an indication that this aphorism, too, is

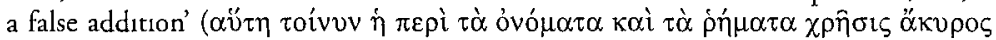

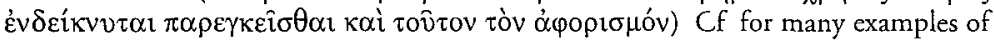
this kind of argument in textual criticism, Brocker (1885) $421 \mathrm{ff}$

13 Sluter (1990) $23 \mathrm{n} \mathrm{91,} \mathrm{of} \mathrm{Gal} \mathrm{De} \mathrm{pulsuum} \mathrm{differentzis} 25$ (8587 K)

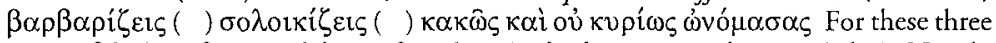
types of faults, of e g Polybius of Sardes, De barbarismo et soloecismo (ed A Nauck, Lexzcon Vindobonense, Hildesheim 1965 [repr of Petersburg 1867], 2831 ff), PsHerodianus, De soloectsmo et barbartsmo, ibid $2955 \mathrm{ff}$ 
mitting a barbarism, ${ }^{14}$ and the occasional solecism in a work of undisputed authenticity is waved aside because Galen feels it does not at all affect our understanding of what is intended ${ }^{15}$ A good example is the indifferent use of the feminıne or masculine gender for the word lithos, 'stone' Galen ridicules the exaggerated reaction of purists, who cry out at each allegedly misconstrued 'stone', as if they had been knocked on the head with it In fact, the masculine gender is normal in both ancient and medical practice, and the word itself is perfectly understandable in whichever gender it is being used ${ }^{16}$ Generally speakıng, Hippocrates may use extremely concise expressions, but he does not normally misconstrue his sentences ${ }^{17}$ Admittedly, Hippocrates is not all that precise in the use of technical terminology, but on the other hand, Marinus' attempt to explain one of the Aphorisms by assuming an inaccurate choice of words on the part of Hippocrates is rejected 18 In fact, such inaccuracy may again be used as an argument against the authenticity of an aphorism ${ }^{19}$ Galen prefers to claim that Huppocrates is not fussy or pedantic about his choice of words, a characteristıc the latter shares with the other ancients Galen even manages to turn it into a definite asset, as we shall see

Hippocrates' choice of words brings us to his stylistic characteristics With the other ancient authors he shares a strong and impressive, if somewhat rough and ready style This judgement is summed up in the qualification deinotês, 'rhetorical power, forcefulness' $20 \mathrm{H}$ is rhetorical power manifests itself in extreme conciseness or rapidity 21 We may connect this with his use of

14 Although his distınction between barbarısm and solecism does not seem to be altogether clear-cut

$15 \mathrm{Cf}$ for this relative indifference to linguistic expression In Hippocratis Epidemiarum librum I commentari 56 (18A $167 \mathrm{~K}$ ) The usual reading is

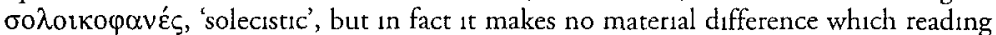

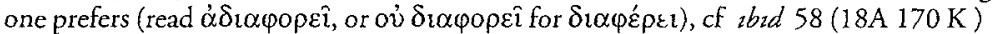

16 De sumplicuum medicamentorum temperamentıs ac facultatzbus $92(12193 \mathrm{f} \mathrm{K})$

17 Cf In Hipp Prorrhet comment $14(16511 \mathrm{~K})$, a nice example is Galen's dis-

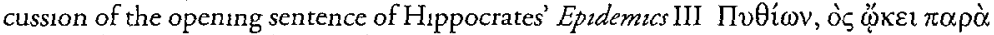

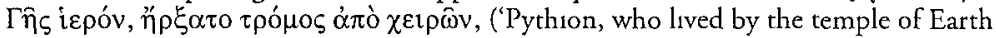
- a trembling began from his hands') Galen suggests that the nominative Pythion and the following relative clause can be explaned as the label of the case, as it were Hence, Hippocrates would be making a fresh start from $\eta p \xi \alpha \tau o$ Galen proceeds with the words 'It is better to explain his words in this way, than to be forced to assume that Hippocrates committed an error of construction on purpose, right at the beginning of this work The more so, since it would be the only one in the whole work' (In Hipp Eprd III comment 11 (17A $480 \mathrm{~K})$

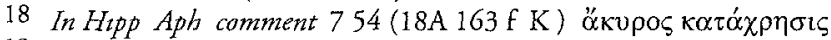

19 In Hipp Aph comment 769 (18A $183 \mathrm{f} \mathrm{K}$ ), cf Brocker (1885) 422, 427

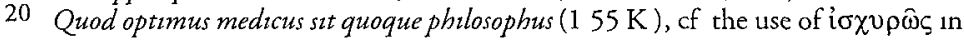
De elementis secundum Hippocratem 13 (1 $434 \mathrm{~K})$

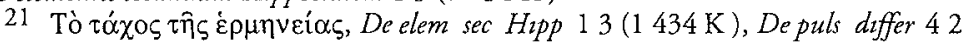

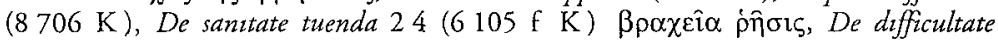
respirationts $27(7851 \mathrm{~K})$, De cristbus $19(9584 \mathrm{~K})$, De meth med $44(10274 \mathrm{f}$ 
asyndeton, for instance, although Galen does not explicitly make this link 22 Hippocrates is entırely free from kakozêlia, 'affectatıon', the very opposite of forcefulness 'Affected' speech falls flat for trying too hard to be brilliant and daring, ${ }^{23}$ where Hippocrates is concerned, it is a sure sign of inauthenticity or corruption 24 The unfortunate Archigenes, Galen's arch-enemy, is inevitably charged with this stylistic defect 25 In the Commentary on Eprdemics III, ${ }^{26}$ a certain variant is rejected, because it would be the only case of bad affectation in a book that is otherwise written polittkôs, in ordinary educated language 'Political' is a typical prose-style qualification, ${ }^{27}$ referring to normal proper usage, as opposed to 'rhetorical' language ${ }^{28}$ Galen perceives a stylistic resemblance between Hippocrates and Xenophon in this respect ${ }^{29}$ Although Hippocrates does employ 'difficult words', or words in a pregnant sense, ${ }^{30}$ he would nevertheless usually stıck to ordınary colloquial usage, ${ }^{31}$ or at least to the ordinary medical usage of his day, ${ }^{32}$ eschewing the far-fetched and artıficral technical vocabulary that the younger generation of doctors relished 33 Hippocrates and his generation want to make themselves understood, no mat-

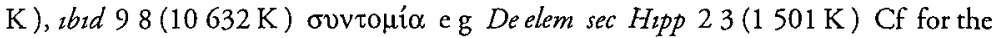
connection between forcefulness and brevity/rapidity, Ps -Demetrius, De elocutzone 242,253

22 In Hipp Epid I comment 32 (17A $224 \mathrm{~K}$ ), of for the connection between asyndeton and brevity, Ps -Demetrius, De eloc 269,271

23 Lausberg (1960) $\$ 1073$, cf Brocker (1885) 417

24 In Hipp Aph comment 767 (18A $179 \mathrm{~K})$, In Hipp Epid III comment 213 (17A $639 \mathrm{~K}$ ), cf In Hipp Eptd $V$ T comment 29 (17A $909 \mathrm{~K}$ ), ibid 521 (17B 282 $\mathrm{K}$ ), for which of Palladius, In Hippocratzs librum sextum De morbss popularibus commentaru 21423 (Dietz)

25 De locts affectzs $28(8100 \mathrm{~K})$

$26373(17 \mathrm{~A} 751 \mathrm{~K})$

27 Cf Isocrates 910 poetry is metrical, rhythmical and has a wide range in its chorce of words, including foreign ones, neologisms and metaphors Prose on the other

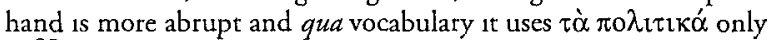

28 Aristotle, Poetzcs 1450 b 7

29 In Hipp Artic comment 168 (18A $414 \mathrm{f} \mathrm{K})$

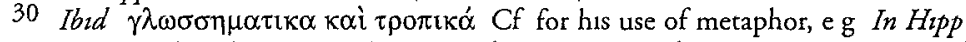
Artic comment $450(18 \mathrm{~A} 750 \mathrm{~K})$ For another comparison between Hippocrates and Xenophon, see In Hipp Artic comment 1 praef (18A $301 \mathrm{~K})$

31 De meth med 65 (10 424 K)

$32 \mathrm{Cf}$ Quod optrmus medicus sit quoque philosophus $(155 \mathrm{~K})$, De alimentorum facultatzbus 339 (6 $742 \mathrm{~K})$

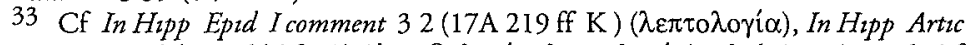

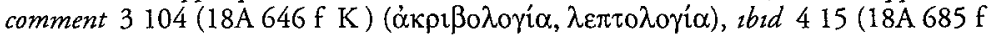
K) ( $\mu$ iкро $\lambda \circ \gamma i \alpha$, associated with the sophists, and particularly with Prodicus) Galen shows an awareness of the fact that language and terminology may change over time Even though Hippocrates keeps to the normal usage of his own day, there may still be a discrepancy between his terminology and that of Galen's contemporaries 
ter how They display a superior indifference to stylistic niceties ${ }^{34}$ It is easy to see that this is the prvotal point of Galen's overall judgement Hippocrates' preference for normal words, for the sunêthera (and thus his 'political' style), implies an aversion to everything far-fetched and over-sophisticated (kakozêlon) And in turn this produces the kınd of straightforward, concise style that makes an impression of impetus and rhetorical power

If we compare the stylistic characteristics attributed to Hippocrates by Galen with the 'standard' rhetorical list of the virtues of style, we find that he does not do too badly By the time of Galen, rhetorical handbooks would suggest quite a sophisticated array of such virtues However, the four virtues distinguished by Theophrastus were still at the basis of them all These were 'hellenism', or purity of language, clarity, ornament and propriety The last two were often more or less merged, 35 while brevity might be added as a fifth (or fourth) positive qualification. This was the particular contribution of the Storcs, who regarded it as a desirable characteristic of discourse under all circumstances 36

Now, Galen claims that Hippocrates' language tends to be correct, as we have seen above Brevity reigns supreme throughout his works, ${ }^{37}$ and usually he is clear, ${ }^{38}$ although Galen does feel compelled to qualıfy this judgement, as we shall see shortly Ornament, however, in the sense of an ample use of figures and tropes, is hardly ever referred to in analyses of his texts, and indeed the emphasis on straightforwardness suggests that there hardly was any On the other hand, rhetorical power or forcefulness may be subsumed under the general caption of ornament, ${ }^{39}$ so that Hippocrates scores again

The virtues of brevity and clarity bear a somewhat straned relationship to each other, as Galen realizes Ideally, they should go hand in hand to effect a perfect style Galen quite explicitly declares that he regards a combination of clarity and brevity as ideal ${ }^{40}$ However, brevity involves the danger of obscurity, and in fact people do tend to misunderstand Hippocrates because of $1 \mathrm{tt},{ }^{41}$

34 In Hippocratts librum De fracturıs commentart 273 (18B $526 \mathrm{f} \mathrm{K}$ ) (esp $\tau \grave{\eta} v$

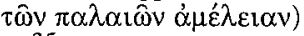

35 Cf Lausberg (1960) $\$ 458 \mathrm{ff}$

36 Pearcy (1983) does not mention this at all See Atherton (1988) $411 \mathrm{f}$ Traditionally, brevity would be recommended for the narratio and the summary only, of Lausberg (1960) $\$ 297$

37 Galen is no friend of the Stoics, but as so often, it is probable that here, too, Storc ideas have become common good in educated crcles Cf Frede (1981) 70

38 Cf In Hipp Fract comment $329(18 \mathrm{~B} 576 \mathrm{f} \mathrm{K})$

39 Lausberg $(1960) \$ 540$

$40 \mathrm{Eg}$ De puls differ $42(8717 \mathrm{f} \mathrm{K})$, De anatomicts administrationtbus 12 (2 $220 \mathrm{~K})$, et saep

41 Cf De san tuenda 24 (6 105 f K), De crts 19 (9584 K), De meth med 65 $(10425 \mathrm{~K})$, In Hipp Fract comment 11 (18B $326 \mathrm{~K})$ 
which is the main reason why a commentary is required in the first place ${ }^{42}-$ fortunately Galen seems to have had no problems at all I will return to this point in section three

\section{Authority and defectrve literary mertt}

Galen had obviously been working hard to make his linguistic report on Hippocrates as favourable as possible In section three we shall look more closely at the theory he uses to back up his claims But in anticipation of my results there, I would !ike to draw attention to an interesting parallel For, apart from students of medicine, there was yet another group of scholars who used philology as their technical equipment, although their interests were not primarily linguistic at all I am referring to the early Christian authors workung on the text of the Bible

From a very early date onwards, early Christian authors had felt some uneasiness about the stylistic level of the text they otherwise looked upon as the summit of wisdom and the ultimate authority for human conduct ${ }^{43}$ In other words, here, too, it was the cognitive (or rather religious) contents for which these texts were studied, and agan technical philology was the framework withın which this was mostly done From the very start, Christian apologists felt the need to defend the extreme stylistic simplicity of the language of the Bible, which seemed to lack any of the sophistication inherent in classical literature, and so formed an easy target for pagan mockery And later, when more and more philological efforts were made to provide edittons and translations of, and commentaries on, these texts, the linguistic framework would inevitably bring along questions of tts own about the literary value of the Bible - the same kind of questions Galen had to face about Hippocrates All educated Christians would work within this linguistic framework For they would all have enjoyed a thorough pagan linguistic training in the disciplines of grammar, rhetoric and logic Their solution to the dilemma is remarkably similar to what we will find in Galen they claimed the superiority of their lingua piscatoria, 'the language of the fishermen', over the sham-embellishments of empty rhetors ${ }^{44}$ They announced that in therr eyes there could be only one vital virtue of speech, namely clarity, even if this was attained at the cost of flawed grammar the truth of Scripture could not be bothered with the stratght-jacket of the 'rules of Donatus' 45 Simplicity was equated with truthfulness and nothing was allowed to stand in the way of comprehensibility

42 De meth med $98(10632 \mathrm{~K})$

43 Cf Auerbach (1958) $39 \mathrm{ff}$

44 Cf Norden $\left(1909^{2}\right) 512 \mathrm{ff}$, esp 516, Auerbach (1958) $22 \mathrm{ff}$, Hagendahl (1959) passzm, Fuchs (1971) 38

45 See Gregory of Tours, In gloria confessorum (preface) 
Augustıne gave up the traditional idea that style should correspond to subject-matter there could be no doubt about the solemn sublımity of the contents of the Brble Yet, when one's aim was to teach or to explain, one's style should be simple 46 The stylistic ideal following from these principles was summed up by Augustine's motto of dilngens neglegentra, 'a careful indifference', which recalls Galen's remark on the stylistic 'superior indifference' of the ancient doctors 47 Of course, early Christran authors would clam that they adapted their own style to the norms set by the Bible - even if they did not 48 Augustine provides a nice example of the internal struggle that this stylistic norm could cause 49

Incidentally, the same line of defence was used in the case of (pagan) philosophers They, too, could not be bothered with minute linguistic distinctıons therr philosophical ideas were all that counted, and as long as they succeeded in makung themselves understood, linguistic criticism was uncalled for Remarks to this effect can be found about Chrysippus - right alongside complımentary statements about his remarkable contributions to the study of linguistics --, Plotinus and Epictetus 50 The argument used here consists of the opposition of pragmata, 'contents', and rhêmata, '(mere) words', and it recurs in the context of philosophical discussion, the Bible and medicine alike Epicurus, too, could be mentioned in this context according to Diogenes Laertius 'the terms he used for things were the ordinary terms ( ) He was so lucid a writer that in the work On Rhetoric he makes clarity the sole requisite' 51 And although for Arsstotle linguistic purtty is an absolute prerequisite, the first real virtue is clarity 52

\section{Galen's defence of Hippocrates}

Returning to ancient medicine, we observe that Galen employed two slightly different tactics to achieve one goal, viz to justify Hippocrates' style The first

46 Aug De doctrina christzana 41024,41227 Cf Auerbach (1958) $32 \mathrm{f}$ In itself this latter idea was sound classical rhetorical theory, of Cicero, Orator $69 \mathrm{ff}$ If Cicero allows an unadorned style now and then, it is never irrespective of the subject-matter, of De finibus bonorum et malorum 319

47 See note 34 Cf Aug Doctr chr 41024 , cf De beata vita 31

48 Cf the examples of highly rhetorically phrased disclaimers of rhetoric collected by Norden $\left(1909^{2}\right) 512-534$

49 Cf Aug Confessiones 359 and Doctr chr 469 ff, see Fuchs (1971) $43 \mathrm{ff}$

50 Chrysippus of Hulser (1987-1988), fr 601E (and references), Gal De placttis Hippocratis et Platonis 25 ( $5253 \mathrm{~K}$ ), Diogenes Laertius 7 180, Epictetus Diatribae 39 13-14, Porphyry, Vita Plotinz 8, 13

51 Diog Laert $1013-14$ (transl Hicks, $L C L$ )

52 Purity Arist Rhetort 35 (1407 a 19), clanity abzd 32 (1404 b 1-3) If language is unclear, in a way it farls to be language This idea is picked up by Galen in his De captionibus $2(96,13 \mathrm{f}$ Edlow, $14589 \mathrm{~K})$ 
consists of the claim that Hippocrates' style is actually identical to the ideal style - and, incidentally, to Galen's own The second consists of putting Hippocrates' stylistic performance in a special kind of context, and claiming its perfect surtability to that context Galen discusses the genre of 'scientific instruction' in connection with this

\section{The proclamation of a stylistzc adeal}

Galen's hinguistic ideals, too, may be studied from both a grammatıcal and a rhetorical point of view Grammatically speaking, Galen manntans a permıssive attitude As long as one makes oneself understood, it does not matter whether one's speech is full of barbarisms ${ }^{53}$ And as he puts it elsewhere, 'it is better to commit solecisms and barbarisms in one's language than in one's life' 54 He even wrote a pamphlet against people who tried to fight solecism 55 He is quite explicit about the fact that it is absolutely imperative to stick to normal usage, and to prevent causing unnecessary confusion by introducing obscure technical terminology (which might take the form of seemingly normal words being used in an unexpected sense) ${ }^{56}$ And, of course, he can adduce a very pertinent reason why this should be so the communication with one's patients ${ }^{57}$ Earlier doctors never used other words than the ones they might hear from their patients themselves If a patient's description of his own symptoms is clear and understandable, why introduce impressionist and baroque expressions for different types of pain? And conversely, if no patient would ever use the termınology of an Archigenes to explann what is alling hım, what is the purpose of its introduction' Galen hates all disputes about mere words and emphatically refuses to take part in what he regarded as a perverted sophistic whim, exhorting his readers to concentrate instead on the issues themselves, the pragmata 58 After all, it is Hippocrates' superior medical knowledge, his knowledge of ta pragmata, that makes us forgive him his deficiencies in disposition and style 59 However, the balance is pretty delicate

53 De puls differ $22(8567 \mathrm{f} \mathrm{K})$

54 De ordine hibrorum suorum ad Eugenianum $(1960 \mathrm{~K})$

55 Ibrd, of Delibres proprizs $18(1948 \mathrm{~K})$

56 Examples are legion, eg De alım fac $24(6565 \mathrm{f} \mathrm{K})$, De puls differ 37 (8690 ff K), Synopsss librorum suorum de pulstbus $6(9446 \mathrm{~K})$, De diff resp 12 (7 $758 \mathrm{ff} \mathrm{K})$, In Hippocratzs Prognosttcum commentarz 14 (18B $15 \mathrm{~K}$ )

57 De loc aff 29 (8116 ff $\mathrm{K}$, esp the conclusion $(8118 \mathrm{~K}$ ) 'no pattent expresses what is wrong with him through the words of Archigenes', cf 2 ibld $25(883 \mathrm{~K})$ and De plentudine 2 (7518 K)

$58 \mathrm{Eg}$ De optrma nostrz corporis constitutione 1 (4 $738 \mathrm{f} \mathrm{K})$, De marcore $6(7690$ K), De tumoribus praeter naturam $3(7716 \mathrm{~K})$

59 In Hippocratis librum De acutorum victu commentaru 31 (15626 ff K) The criticism exercised here is in itself a normal feature of the Peripatetic commentary tradition, of Geffcken (1932) 409 The apologetic tone is not ( $ı b z d 410 \mathrm{n} \mathrm{3)}$ 
inaccuracy, or an inadequate command of the facts, combined with stylistic defects may again lead to a denual of authentıcity of (parts of) a treatıse. 60

Galen's insistence on the overruling importance of facts over words and on the need for clear and normal language has its consequences for his 'Kriterien der Sprachrichtigkeit' They are, in fact, nothing other than three forms of sunettheza that of Hippocrates, as the authority par excellence, that of the other ancient doctors, and that of Galen's own day ${ }^{61}$ It $1 s$ this aspect of 'normal usage' rather than that of 'correctness' that Galen emphasizes when he uses the word bellênızeın 62 If Galen uses sunêtheza in both technıcal grammatıcal applications distınguished above (see Introduction above), this is because he actually combines his exegesis of Hippocrates (diorthôszs-type) with criticism of contemporary medical usage and advice about the ideal form it should take (Hellênismos-type) 63

The consequences for Galen's rhetorical and stylistic ideals are clear he advocates a shift in the relative importance of the virtues of style, claiming that his own style is in accordance with this new assessment Galen's permissiveness on the point of grammatıcal correctness makes the virtue of Hellêntsmos recede into the background Contrary to common rhetorical theory, Galen submits that clarity, achieved on the basis of factual accuracy, is the only really important stylistic factor. ${ }^{64}$ If possible, it should be accompanied by brevity ${ }^{65}$ On the other hand, ornament plays no role at all in the way he describes his own style

The only way to mantain a clear style is to conform to normal usage as described above Galen claims this characteristic both for his own style and that of Hippocrates 66 Transparency of meaning is serıously impaired by randomly attributing new meanings to existing words, or by unnecessarily coining new ones Language is a conventional system understanding others and making oneself understood is entirely dependent on whether or not one is prepared to comply with existing consensus about what words mean ${ }^{67}$ As long as one does not unilaterally change this agreement, basically nothing can go wrong in the process of communication Errors in the grammatical construction of the sentence or the formation of individual words will not be fatal In this respect, Galen, like the early Christıan authors and the philoso-

60 In Hipp Acut comment 4, prooem (I5 732 K) See section I (above)

61 De diff resp $12(7758 \mathrm{ff} \mathrm{K})$

62 Cf De meth med $19(1071 \mathrm{~K})$

63 Cf note 33 above

64 Cf De facultatibus naturalibus 1 i (Scripta minora $3101,21 \mathrm{f} \mathrm{K}$ ), cf section 2 in fine

65 De anat admin 1 (2220 K), De puls differ 42 (8717 f K)

66 In Hupp Progn comment $318(18 \mathrm{~B} 267 \mathrm{~K})$

67 Ad Thrasybulum 32 (5867 ff $\mathrm{K}$ ), esp $5868 \mathrm{~K}$ 'it is impossible to find out what a word refers to, unless one is taught by the ones who imposed it' 
phers mentioned in section two, finds himself in complete agreement with the leading grammarians of his day Although originally this distinction between words (as physical things), reference in the outside world and (incorporeal) meaning was of Stoic provenance, by the second century $\mathrm{AD}$ it belonged to the common stock of grammatical assumptions 68

It is interesting to see that Galen realizes that language develops Words may become obsolete, even if they were quite normal in ancient times This is one of the reasons why he does not insist on Atticistic language in his eyes the classical Attıc dialect was a sunêtheza like any other It cannot therefore claim more authority than Galen's contemporary sunêtheza 69

In short, Galen's stylistic ideal coincides with his view of both Hippocrates' and his own style Although in practice his own Greek is faurly Atticistic and well-groomed, he denies that that is at all important in theory His only professed aim is to write a 'normal', clear and concise Greek The degree of conciseness depends on the type of treatise a commentary should be more expansive than an independent treatise ${ }^{70}$ In other words, one should aim for a 'proportional' style ${ }^{71}$ It is stressed throughout that linguistic expression is, in all respects, less important than a clear grasp of factual content

\section{The genre of the epistêmonikê didaskaha}

The framework Galen provides for his view of the ideal style, is that of genre and function Traditionally, ancient rhetorical theory would link up stylistic characteristics with specific literary genres Epic and tragedy would be associated with an elevated style, history would combine elements of a narrative style with poetical overtones, and forensic oratory should be more straightforward, since here it was necessary to get across a message Of course, this did not preclude stylistic variation withın any genre On the contrary, the different parts of a forensic speech required different levels of style in order to be maximally effective On a theoretical level this was connected with the notion of function Of the three basic functions of rhetoric, to instruct, to move and to delight, the first was best fulfilled by means of the simple style, ${ }^{72}$ the second by the elevated and the third by an intermediate level of speech As we saw, Augustine made use of this rhetorical doctrine, and so did Galen

68 Sluiter (1990) $26 \mathrm{ff}, 64 \mathrm{f}, \mathrm{cf}$ for the influence of the Stoa, Frede (1981) 70 Pearcy $(1983,261)$ wrongly opposes Galen's indifference in matters of vocabulary to the Storc theory of the natural correspondence between words and things In fact, Galen's view that meanıng cannot really be damaged by deficient words, is x emarkably similar to the Storcs', whether Galen would have liked it or not

69 Cf De compositione medicamentorum per genera $110(13408 \mathrm{~K})$, see Kollesch (1981) 5

70 In Htpp Aph comment 7, proœm (18A $102 \mathrm{~K}$ )

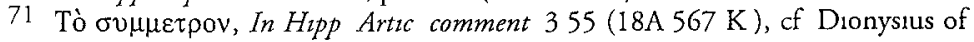
Halıcarnassus, Isaeus 203 , Ps-Dion Hal Ars rbetorica 1041

72 Cf Lausberg (1960) \$1079 
On various occasions, Galen mentions the so-called epıstêmonikê didaskalia, 'scientific instruction', which he apparently regarded as a specific type of writing, which required very specific stylistic features I would suggest that in this type of writing the notions of genre and function merge Like the early Christian authors, Galen has no doubt about the relevance and sublımity of his subject-matter, but he still advocates a simple style in view of the general didactıc purpose of medical writings 73 Unsurprisingly, the characteristics of this style show a marked resemblance to that of Hippocrates as analysed by Galen authors of this type of work should use words in their proper sense without resortıng to unnecessary metaphors, if the proper terms are lacking, they should rather take recourse to circumscription ${ }^{74}$ Furthermore, they should concentrate on content, not on words 75 In an epistêmonikê didaskalia 'it suffices to mention a word, to indicate its meaning as the instructor intends to use $1 \mathrm{t}$, and then to proceed to the explanation of whatever is the $15 s u e^{\prime} .{ }^{76}$ This is again to insist on the conventional character of any terminology, which, in turn, implies that any use of language that is helpful to the audience is permitted 77 Obscurity should be avoided at all costs, for 'unclear language does not teach anythıng' - again Augustıne offers a strıkıng parallel when he says 'Anyone who teaches shall avold all words that do not teach anythıng' 78 Galen does make a distinction, however, between works intended for beginners and those intended for advanced students If one is addressing an advanced student, metaphors, or words used in an improper sense, may be allowed for the sake of brevity ${ }^{79}$ But when instructing beginners, optimal clarity is essential A teacher should use the most natural language possible in order to achieve maximal clarity 80

\section{The difference between Galen and Hippocrates}

This distinction of intended audiences helps Galen to come to grips with a remaining nettling problem he had to explain why a commentary on Hippocrates was necessary at all and to give an indication of how he himself could be of help in that respect How could he be expected to explain Hippocrates, if their styles were identical, while that of Hippocrates was ideal to begin with 281

\footnotetext{
73 Cf section 2 and note 46 above

74 De puls differ $36(8675 \mathrm{~K})$, cf De loc aff $26(887 \mathrm{~K})$

75 De meth med $149(10972 \mathrm{~K})$

76 De loc aff $13(832 \mathrm{~K})$

77 De meth med $16(1047 \mathrm{~K})$

78 Cf Gal In Hipp Acut comment $416(15761 \mathrm{~K})$, and In Hipp Prorrhet com-

ment 115 (16 546 K) with Augustine, Doctr chr 41024

79 De puls differ $36(8675 \mathrm{~K})$, cf ibud $42(8717 \mathrm{f} \mathrm{K})$

80 De simplicuum medicamentorum temperamentzs ac facultatibus $92(12194 \mathrm{~K})$, of on the relationship between style and intended audience, Manulı (1983) 473, 476, In Hipp Fract comment 1, praef (18B $321 \mathrm{~K}$ )

81 Cf Manulı (1983) on the problem of the justification of Galen's commentares
} 
In order to solve this dilemma, Galen points out a number of characteristics peculiar to Hippocrates' style of teaching and perfectly acceptable in the context in which the latter worked $\mathrm{He}$ also refers to the particular exigencies of his own day, and firmly puts his exegetical work in a different didactic context from that of Huppocrates

Hippocratıc succinctness has been mentioned several times already, it is the main reason any explanation at all is required Hippocrates is in the habit of teaching complete theories through one or two incidents ${ }^{82}$ His theoretical doctrines come more or less as a by-product of his writings, ${ }^{83}$ as when he remarks in passing on the absence of certain symptoms The attentive reader may deduce from this that according to Hippocrates such symptoms would usually occur However, Hippocrates refrains from making this explicit 84

Moreover, Hippocrates' language is not that of a contemporary doctor even though he stıcks to his own sunêtheia, words may have changed or become obsolete over time ${ }^{85}$ This makes Hippocrates a difficult author for an untraned reader However, to anyone who has recerved any training and who is used to reading older literature, his style is perfectly clear ${ }^{86}$ Since meaning depends on convention, Galen is very impatient about using etymology in a scientific context, ${ }^{87}$ another linguistic topic to which he dedicated a separate treatise 88 If he mentions an etymology at all, he usually does so in a somewhat apologetic or derisive way, referring for instance to 'those people who enjoy etymologies' 89 The widely accepted clam of the Stoics that etymology can teach us the true meaning of a word is clearly not one Galen would readily approve of 90 The context will usually prove sufficient to provide a clear understanding of the meaning of any uncommon words Grammarians successfully apply this technique to both Homer and other ancients, and Galen propagates it for the study of Huppocrates ${ }^{91}$ However, since Galen envisages a wider audience for the works of Hippocrates than just the specialist, he sets himself the task of eliminating even the smallest obscurıtıes - and this is one

82 In Hipp Off med comment 318 (18B 845 K)

83 In Hipp Epad I comment 217 (17A $110 \mathrm{~K})$

84 In Hipp Epid I comment $217(17 \mathrm{~A} 110 \mathrm{~K})$, De comate secundum Hippocratem $2(7650 \mathrm{~K})$, De diff resp $27(7851 \mathrm{~K})$

85 De comp med per gen $110(13408 \mathrm{~K})$, Linguarum seu dictnonum exoletarum Hippocratis explicatio (1963 K)

86 In Hipp Artzc comment 11 (18A $303 \mathrm{f} \mathrm{K})$

87 Cf De Lacy (1966) 264, e g De plac Hipp et Plat 22 (5213 f K)

88 Cf De plac Hipp et Plat $22(5214 \mathrm{~K})$

89 In Hupp Artic comment $127(18 \mathrm{~A} 359 \mathrm{~K})$, In Hipp Fract comment 120 (18B $364 \mathrm{~K}$ )

90 Sluiter (1990) $18 \mathrm{ff}$

K)

91 De puls differ $42(8715 \mathrm{f} \mathrm{K})$, of In Hipp Prorrbet comment $3115(16706$ 
raison d'être of his commentaries. This same distinction between beginners and advanced students recurs elsewhere, as an excuse for what might be considered excessive explanation..$^{92}$

\section{The philological paradigm and the embarrassment of imperfection}

We have come to the end of this brief survey and may sum up as follows: In Galen's day the combination of current schoolpractice - which had an essentially linguistic orientation - with a generally positive attitude to authority favoured a philological approach to technical problems: Not only in literature were authoritative ancient texts being put on a pedestal as touchstones of grammatical correctness and stylistic beauty, but in other areas, too, people looked back to a remote past in which remarkable achievements had been realized, if only in nuce. In any disciplines in which a text or corpus of texts assumed such a place of prominence, philology claimed its due as the most suitable technical method to tackle such a subject. The most outstanding examples of this phenomenon are ancient medicine and ancient Biblical exegesis.

From Origen onwards, early Christian authors applied all the technical tools of pagan classical philology to the study of their most authoritative texts, the Bible. The sheer quantity of early Christian literature helps us to acquire an idea of how inescapable the 'philological paradigm' was and of the tensions it caused. The clash between a linguistic approach that automatically took the form of a text as point of attack and the unique value attached to the informational contents of these texts did not escape any of the practitioners of this method. When forced by their instrumentarium to judge the grammatical correctness and the rhetorical qualities of these texts, early Christian exegetes did not refuse to do so, but they propagated new norms.

Approximately half a century before Origen we can witness this same struggle in Galen, who anticipates the Christian answers. On the one hand Galen exploits the 'philological paradigm' for his own purposes, promoting as he did Hippocrates' status of the ultimate source of medical knowledge, by telescoping the second-century state of the art into Hippoctatic medicine. On the other hand he has to face the problem that Hippocrates does not live up to the literary standards inherent in the philological model.

His solution to this dilemma was to declare that a master-doctor cannot be measured by literary norms without qualification. In teaching, content takes precedence over form, and clarity over grammatical correctness. In Christian eyes, only pagans would insist on verbal precision; Galen reproaches the

92 In Hipp. Fract. comment. 1, procm. (18B.320 K.). 
'younger doctors' with exactly the same pettiness. This is contrasted with the superior indifference of the ancients - or the Bible - towards trifling linguistic details. The epistêmonikê didaskalia has its own stylistic requirements and these are easily met by both Hippocrates and Galen himself. If exegesis is necessary at all, this is due to a difference in didactic context. Galen tries to find a basis and confirmation for contemporary medicine in Hippocrates - a strictly medical and technical project, but all the while he foots his argument on a philological basis, following his convictions of what is truly Hippocratic writing and language, 93 and asking questions which are forced on him by his critical instrumentarium. At the same time, however, the heart of grammatical studies, the concern for correctness, is watered down, if not given up altogether. This was the price for a way out of the embarrassment of imperfection.

93 Cf. Bröcker (1885) 432; 438. 


\section{BIBLIOGRAPHY}

Atherton, C (1988), 'Hand over fist The fallure of Storc rhetoric', The Classzcal Quarterly 38, 392-427

Blank, D L (1982), Anctent Phulosophy and Grammar The Syntax of Apollonus Dyscolus (American Classical Studies 10), Chico Californıa

Brocker, L O (1885), 'Die Methoden Galens in der literarıschen Kritık', Rhernisches Museum 40, 415-430

Deichgraber, K (1965), Due grechische Empirkerschule, Berlın

De Lacy, Ph (1966), 'Galen and the Greek Poets', Greek, Roman and Byzantzne Studzes $7,259-266$

Frede, M (1981), 'On Galen's epistemology', in V Nutton (ed), Galen Problems and Prospects A Collection of Papers submitted at the 1979 Cambridge Conference, London, 65-86

Fuchs, H (1971), 'Die fruhe christliche Kurche und die antıke Bildung', in R Klenn (ed), Das frube Christentum im romischen Staat (Wege der Forschung 267), Darmstadt, 33-46

Geffcken, J (1932), 'Zur Entstehung und zum Wesen des griechischen wissenschaftlichen Kommentars', Hermes 67, 397-412

Hagendahl, H (1959), 'Piscatorie et non Aristotelice Zu einem Schlagwort ber den Kirchenvatern' in Septentronalia et Occidentalia, Studia B Karlgren dedicata, Stockholm, 184-193

Ilberg, J (1890), 'Die Hippokratesausgaben des Artemidorus Kapiton und Dioskorides', Rheinzsches Museum 45, 111-137

Kollesch, J (1981), 'Galen und die zweite Sophistık', in V Nutton (ed), Galen Problems and Prospects A Collection of Papers submitted at the 1979 Cambridge Conference, London, 1-11

Lausberg, H (1960), Handbuch der literartschen Rhetorik, 2 Vols, Munich

Manul, P (1983), 'Lo stıle del commento', in F Lasserre and Ph Mudry (eds), Formes de la Pensée dans la Collection Hippocratzque Actes du IVe Colloque international Hippocratique (Lausanne, 21-26 septembre 1981), Geneva, 471-480

Mewaldt, J (1909), 'Galenos uber echte und unechte Hippocratica', Hermes 44, 111 134

Muller, I von (1891), 'Galen als Philologe', Berliner Philologische Wochenschruft 1125 , 799-800

- (1892), 'Galen als Philologe', Verhandlungen der 41 Versammlung der deutschen Philologen und Schulmeister in Munchen, 80-91

Norden, E (19092), Die antzke Kunstprosa vom VI Jahrbundert v Chr bis in die Zett der Renazsance, Leipzig - Berlın

Pearcy, L T (1983), 'Galen and Storc rhetoric', Greek, Roman and Byzantıne Studres 24, 259-272

Stebenborn, E (1976), Dze Lehre von der Sprachrichtzgkett und zbren Krtterzen Studien zur antzken normatzven Grammatzk, Amsterdam

Sluiter, I (1990), Anctent Grammar in Context Contributions to the Study of Ancient Linguistic Thought, Amsterdam

Smith, WD (1979), The Hippocratic Tradition, Ithaca

Temkun, O (1973), Galentsm Rise and Decline of a Medical Philosophy, Ithaca - London

Vegettı, M (1981), 'Modelli di medicina in Galeno', in V Nutton (ed), Galen Problems and Prospects A Collection of Papers submitted at the 1979 Cambridge Conference, London, 47-63

Wellmann, M (1931), Hippokratesglossare, Berlin 